\title{
First Report of the Occurrence of Banana Streak Goldfinger Virus (BSGFV)in the State of Minas Gerais, Brazil
}

\author{
Farias ARG, Figueira AR*, Geraldino PS and Pompeu DC \\ Departamentof Phytopathology, Federal Universityof Lavras -MG, Brazil
}

Submission: October 02, 2018; Published: September 04, 2018

*Corresponding author: Figueira AR, Departament of Phytopathology, Molecular Virology Laboratry, Federal Universityof Lavras -MG-Brazil, Tel: +55-(35)-3829-1282; E-mail: antoniarfigueira@gmail.com

\begin{abstract}
The leaf streakviral disease inbanana plants iscaused by a species complex known as Banana Streak virus(BSV). In Brazil, there have been few studies concerningthese species, Butcharacterizing them is necessary to determine which species are endemicin the field. To this end, banana leaf samples were collected from different producing regions of Brazil. Their total extracted DNA was then subjected to Polymerase Chain Reaction (PCR)employing theBadna-FP/-RP primers to amplify a 540-base-pair (bp) fragment located in the gene that encodesRT/Rnase H, which is usedto differentiate Badnavirus species.The positive samples were confirmed by Rolling Circle Amplification (RCA) using the Illustra TempliPhi 100 Amplification Kit. The 540-bp genome fragment wassequenced and the results analyzed and compared with the Badnavirus species available inthe GenBank database. The nucleotide sequence of the isolate designated MGJAPI, when compared to the GenBank BSGFV isolates, showed the lowest identity percentage,91\%, with the Uganda isolate (AJ968435). When compared to other isolates, the identities ranged from $97 \%$ to 99\%.Thus, according to the International Committee on the Taxonomy of Viruses (ICTV) classification criteria, the isolate MGJAPI belongs to the species Banana streak Goldfinger virus (BSGFV) and this is the first reportof the occurrence of this species in the state of Minas Gerais, Brazil..

Keywords: leaf streakviral disease; plants; Badnavirus species; Goldfinger virus; seedlings; Cucumber mosaic virus; Uganda virus; Planococcus citriand; Saccharicoccus sacchari; banana; Vietnam virus; Climate; pathogens; Brazilian farmers; Amino acid; Percentage; Amino acid; Cladograms; Crop; Fruit
\end{abstract}

Abbreviations: BVS: Banana Streak virus; PCR: Polymerase Chain Reaction; RCA: Rolling Circle Amplification; ICTV: International Committee on Taxonomy of Viruses; UPGMA: Unweighted Pair Group Method with Arithmetic

\section{Introduction}

Brazil is the fourth-largest producer of bananas in the world, cultivatingabout seven million tons overan area of approximately 500,000 hectares.The favorable Brazilian climate enables the productionof fruit year-round (FAO, 2012). As favorable as the climate is for producing bananas, it is also favorable forthe development of several pathogens, which increasethe cost of production and constitute a serious challenge for Brazilian farmers. The propagation of healthy seedlings has been one of the most important phytosanitary measuresfor controlling these diseases, especially when it comes to viral diseases [1]. This is because once infected,plants cannot be cured and must be eliminated from the crop, causing undesirable losses.

There are two viral diseasesfound in the banana tree in Brazil:infectious chlorosis of banana, caused by the Cucumber Mosaic Virus (CMV), and the other is banana leaf streak, caused by the Badnavirus species [2]. However, the process of indexing seedlings to a diagnosis of Badnavirus is quite complicated, since in addition to presenting high genetic variability, Badnavirus species associated with banana streak are able to integratesome or all of their DNA into the banana plant's genome, compromising the efficiency of serological and molecular testing techniques [3$6]$.

In addition to the Banana streak virus (BSV), other species of Badnavirus associated with banana streak, such as Banana streak Mysore virus (BSMyV), Banana streak OL virus (BSOLV), and Banana streak GF virus (BSGFV) have already been well characterized $[7,8]$. However, as the genomes of the different isolates that have been found are sequenced, new species appear, such as Banana streak acuminata Vietnam virus (BSAcVNV) [9], Banana streak Cavendish virus (BSCavV) [10], Banana streak Imové virus (BSImV),Banana streak Uganda A-M virus(BSUgBV) $[11,8]$, and many others. This has hampered the taxonomic classification of this virus, and sometimes the isolates 
are identified asBSV species but, in fact, the BSV was only the first species of the genus Badnavirus described in banana. The main vectors that disseminate these species in the field are the mealybugs Planococcus citriand Saccharicoccus sacchari, but it has not been ruled out that they can also be transmitted by other species of mealybug $[12,13]$.

In Brazil, the Badnavirus species associated withbanana streakthat have been described so far areBanana streak Uganda virus (BSUgBV) $[14,15]$ and Banana streak OL virus(BSOLV). Other genetic variants, called BRSV-BR1, BRSV-BR2, BRSV-BR3, and BRSV-BR4, have also been described by Figueiredo et al. [16], but have not been characterized genetically.This study describes a species of Badnavirus not previously reported in Brazil.

\section{Materials and Methods}

\section{Virus isolates: origin and maintenance}

Samples of banana plants suspected of being infected with $\mathrm{BSV}$ were collected in different regions of the countryduring visits to fields, tissue culture laboratories, and with the collaboration of professionals working in banana production whosent them by mail or other appropriate transport.

\section{PCR, sequencing, sequence analysis}

After extracting the total DNA from samples of the potentiallyinfected leaves, the remaining leaves were stored in a freezer at $-80{ }^{\circ} \mathrm{C}$ anddesiccated for future use. Samples of bananaleaves that were cultivated in a controlled greenhouse environmentat the Federal University of Lavras (UFLA), and which proved to be virus-free, were used as negative controls.

Total DNA from the healthy and infected leaves was extracted, following the manufacturer's instructions for the Extract-N-Amp Plant PCR kit (Sigma Aldrich)and stored at $-80{ }^{\circ} \mathrm{C}$ for later use. The DNA samples were submitted to PCR (polymerase chain reaction) and the positive samples were again analyzed by RCA (rolling circle amplification)following the methodology described by James et al. [6], to verify if the amplified sequences were episomal. PCR was performed using the primers Badna FP and Badna RP [17], which amplify a fragment of 540 base pairs, corresponding to part of the encoding region RT/RnaseH of Badnavirus.After confirmation of DNA amplification by conventional PCR, the samples were submitted to RCA, following the recommendations of the manufacturer's manualfor the Illustra TempliPhi 100 Amplification Kit (GE Healthcare, Buckingamshire, United Kingdom).The samples' DNA (1 $\mu \mathrm{l})$ was added to $5 \mu \mathrm{l}$ of buffer and $1 \mu \mathrm{l}$ of each primer at the concentration of $60 \mu \mathrm{M}$. The mixture was incubated at $95^{\circ} \mathrm{Cfor} 3$ minutes and then $5 \mu$ l of reaction buffer,previously mixed with $0.2 \mu$ lof phi2 9 DNA polymerase,was added. The reaction was incubated at $30^{\circ} \mathrm{C}$ for 12 hours and stopped with incubation at $65^{\circ} \mathrm{C}$ for 10 minutes.

The genomic fragments of 540 base pairswere sequenced by the company Myleus Biotecnologia and the analyses were carried out using the program NCBI BLAST () [18]. Alignment of the nucleotide and amino acid sequences and the construction of phylogenetic trees was performed using the programs ClustalW2 (Verson 2.0) and Molecular Evolutionary Genetics Analysis - MEGA6 [19], respectively. The characterization of the species followed the criteria of the International Committee on Taxonomy of Viruses (ICTV), which considers a species of Badnavirus sp. as distinct from others by having an identity difference above $20 \%$ in the RT/RnaseH coding region.The phylogenetic relationships were studied using the algorithm neighbor- joining for amino acids and the Unweighted Pair Group Method with Arithmetic Mean (UPGMA)for nucleotides, with 3,000 bootstraprepetitions.

\section{Results}

Comparing the nucleotides of the isolate designated as MGJAPI with the BSGFV isolatesin the GenBank database shows that its lowest identity percentage was 91\%.With isolate AJ968435 from Uganda and with the other isolates used for comparison, it was above $97 \%$, with a maximum of $99 \%$ identity.The lower identity percentage (95\%) forthe amino acid sequence was also observed with the Uganda isolate already cited, and with the other isolates the identity was 98\%.Based on the ICTV criteria, which considers particular isolates to be members of the same species if they share identities above $80 \%$ in the genomic fragment that corresponds to the RT/RNase $\mathrm{H}$, the isolate MGJAPI was identified as BSGFV.

The cladograms based on the sequence of nucleotides and amino acids showed a clear grouping of MGJAPI and BSGFV species, confirming the identity results previously shown.This is the first time that the species BSGFV has beendetected and characterized in Brazil [20].

\section{Conclusion}

There is a wide variety of the Banana streak virusspecies in Brazil.However, Banana streak Goldfinger virus has been identified for the first timein the state of Minas Gerais.New samples are being collected and analyzed to obtain better knowledge of the Badnavirus species present in Brazil.

\section{Acknowledgement}

The authors are grateful to the producers and researchers committed to banana production in Brazil who provided samples for study, and also the Conselho Nacional de Desenvolvimento Científico e Tecnológico (CNPq), the Coordenação de Aperfeiçoamento de Pessoal de Nível Superior (Capes), andthe Fundação de Amparo à Pesquisa do Estado de Minas Gerais (FAPEMIG) for the resource funds to support their current work.

\section{References}

1. Daniells J, Thomas JE, Smith M (1995) Seed transmission of Banana streak virus confirmed. Info Musa 4(1): 1-7.

2. Figueiredo D V, Brioso P ST (2007) PCR multiplex para a detecção de BSV e CMV em bananeiras micropropagadas. Summa Phytopathol. 33(3): 229-232.

3. Staginnus C, Richert-Pöggler K R (2006) Endogenous pararetroviruses: two-faced travelers in the plant genome. Trends Plant Sci 11(10): 485494. 
4. Gayral P, Blondin L, Guidolin O, Carreel F, Hippolyte I et al. (2010) Evolution of Endogenous Sequences of Banana streak virus: What Can We Learn from Banana (Musa sp.) Evolution? J Virol 84 (14): 7346 7359.

5. Iskra-Caruana ML, Gayral P, Galzi S, Laboureau N (2009) How to Control and Prevent the Spread of Banana streak Disease when the Origin Could Be Viral Sequences Integrated in the Banana Genome? International Symposium on Recent Advances in Banana Crop Protection for Sustainable Production and Improved Livelihoods 828:77-84.

6. James A P, Geijskes R J, Dale J L, Harding R M (2011) Development of a Novel Rolling-Circle Amplification Technique to Detect Banana streak virus that also Discriminates Between Integrated and Episomal Virus Sequences. Plant Disease 95(1): 57-62.

7. Hull R, Geering A, Harper G, Lockhart BE, Schoelz JE (2005) Family Caulimoviridae. In: Fauquet CM, et al. (Eds.). Virus Taxonomy. Eight Report of the International Committee on Taxonomy of Viruses. San Diego, USA; Elsevier, pp.385-396.

8. James AP 2011 Viruses of banana in East Africa. Doctor of Philosophy thesis. Queenland University of Tecnology. pp. 1-180.

9. Lheureux F, Laboureau N, Muller E, Lockhart BE, Iskra-Caruana ML (2007) Molecular characterization of banana streak acuminata Vietnam virus isolated from Musa acuminata siamea (banana cultivar). Arch Virol 152(7): 1409-1416.

10. Geering ADW, Mcmichael LA, Dietzgen RG, Thomas JE (2000) Genetic diversity among Banana streak virus isolates from Australia. Phytopathology 90 (8): 921-927.

11. Harper G, Hart D, Moult S, Hull R, Geering A, et al. (2005) The diversity of Banana streak virusisolates in Uganda. Arch Virol 150 (12): 24072420 .
12. Kubiriba J, Legg JP, Tushemereirwe W, Adipala E (2001) Disease spread patterns of Banana streak virus in farmers' fields in Uganda. Annals of Applied Biology 139(1): 31-36.

13. Silveira DG, Meissner Filho, PE, Soares, Sanches TM, Figueiredo DV, NF, (2008) Indexação biológica de genótipos de bananeira para oBanana steak virus. Summa Phytopathologica 34(2): 172-174.

14. Poltronier LS, Figueiredo DV, Brioso PST, Verzignassi R, Cardoso S (2009) Constatação do Banana streak Uganda B virus em bananeiras no estado do Pará. Summa Phytopathologica 35(1): 74.

15. Brioso PST, Pereira JCR, Gasparotto L (2011) Ocurrence of Badnavirus on banana fruits in the state of Amazonas, Brazil. Rev Bra de Frut 33(4): 1353-1355.

16. Figueiredo D, Filho PM, Neto SS, Brioso P (2006) Detecção e análise da variabilidade de seqüências do Banana streak virus (BSV) em bananeiras no Brasil. Summa Phytopathologica 32(2): 118-123.

17. Yang IC, Hafner GJ, Revill PA, Dale JL, Harding RM (2003) Sequence diversity of South Pacific isolates of Taro bacilliform virus and the development of a PCR-based diagnostic test. Arch Virol 148(10): 19571968.

18. http://blast.ncbi.nlm.nih.gov.Blast.cgi

19. Tamura K, Stecher G, Peterson D, Filipski A, Kumar S (2013) MEGA6: Molecular Evolutionary Genetics Analysis Version 6.0. Mol Biol Evol 30(12): 2725-2729.

20. http://www.fao.org/faostat/en/\#data/QC/visualize.

\section{Your next submission with Juniper Publishers will reach you the below assets}

- Quality Editorial service

- Swift Peer Review

- Reprints availability

- E-prints Service

- Manuscript Podcast for convenient understanding

- Global attainment for your research

- Manuscript accessibility in different formats

( Pdf, E-pub, Full Text, Audio)

- Unceasing customer service

Track the below URL for one-step submission https://juniperpublishers.com/online-submission.php 